\title{
Serum creatine kinase B subunit activity in diagnosis of acute myocardial infarction
}

\author{
LARS LJUNGDAHL, WILLIE UIRHARDT, STEFAN HOFVENDAHL \\ From the Departments of Clinical Chemistry and Medicine, County Hospital, S-251 87 Helsingborg, \\ Sweden
}

SUMMARY The value of serum creatine kinase B subunit activity (CK B) in the diagnosis of acute myocardial infarction was studied in 238 consecutive cases. All were admitted to a coronary care unit because of suspected acute myocardial infarction. Serum CK B activity was determined by an immunoinhibition procedure, using a CK $M$ subunit inhibiting antibody (anti-M). For the evaluation of serum CK B, patients were classified into acute myocardial infarction and non-acute myocardial infarction groups. This classification was based on electrocardiographic findings, on quantitative determinations of serum aspartate aminotransferase (AST), alanine aminotransferase (ALT), and total serum creatine kinase (CK) activities, and on qualitative electrophoretic determinations of serum CK and serum lactate dehydrogenase (LD) isoenzymes. The prevalence of acute myocardial infarction in the patient material was $\mathbf{0 . 4 7}$. Serum CK B subunit activity was found to be a highly selective indicator of acute myocardial infarction with a predictive value of a positive test result of 0.97 and a predictive value of a negative test result of 0.99 .

The serum CK B activity increased above the acute myocardial infarction discrimination limit within 12 hours from onset of symptoms.

Two non-acute myocardial infarction patients, who were resuscitated after cardiac arrest, had increased serum CK B values caused by the transient presence of $C K$ isoenzyme $B B$ in serum.

Increase of $\mathrm{CK}^{\star}$ isoenzyme $\mathrm{MB}$ activity in human serum as an indicator of acute myocardial infarction has been well documented. ${ }^{1-6}$ Previously reported methods for the determination of $\mathrm{CK}$ isoenzymes have most often been based upon either electrophoretic or chromatographic procedures. ${ }^{7-11}$ More recently, radioimmunoassays ${ }^{12} 13$ and other immunological procedures ${ }^{14}$ have been developed. We use an immunoinhibition method for determination of CK B subunit dependent activity in human serum. ${ }^{15}$ The application of this immunoinhibition procedure in a group of patients with suspected acute myocardial infarction has been evaluated previously. ${ }^{16}$ The aim of the present study was to obtain further data on the diagnostic ability of the serum CK $B$ determination when used as an indicator of acute myocardial infarction. The clinical usefulness of the assay is compared with

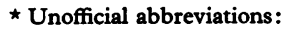

CK, creatine kinase; EC 2.7.3.2.

AST, aspartate aminotransferase; EC 2.6.1.1.

ALT, alanine aminotransferase; EC 2.6.1.2.

LD, lactate dehydrogenase; EC 1.1.1.27.

Received for publication 3 July 1979 that of more traditional enzyme tests and the electrocardiogram.

\section{Subjects and methods}

Included in the study were 238 consecutive cases admitted to a coronary care unit with symptoms indicative of an acute myocardial infarction within the previous 24 hours. Blood samples were drawn on admission and thereafter at six-hour intervals. On each occasion, two samples were centrifuged within one hour. The serum from one was stored at $4^{\circ} \mathrm{C}$ for a maximum of 12 hours before determination of serum AST, ALT, and LD. LD activity, however, was often determined at less frequent intervals. The serum from the other sample was frozen at $-80^{\circ} \mathrm{C}$, immediately after centrifugation, for subsequent total $\mathrm{CK}$ and $\mathrm{CK} B$ determinations. Measurements of total CK, AST, $A L T$, and LD were performed according to the SCE† recommended methods. ${ }^{17} 18 \mathrm{CK} B$ subunit

+ Scandinavian Committee on Enzymes of the Scandinavian Society for Clinical Chemistry and Clinical Physiology. 
dependent activity was determined as residual $\mathrm{CK}$ activity in the SCE CK reaction system after immunoinhibition with a $\mathrm{CK} M$ subunit inhibiting antibody (anti-M). ${ }^{15}$

In the first 113 cases, serum CK B analyses were performed after storage of the samples at $-80^{\circ} \mathrm{C}$ for up to four months. Total serum CK, however, was determined within 24 hours. In the subsequent 125 patient cases, both total serum $\mathrm{CK}$ and serum CK B determinations were carried out within 24 hours.

Control experiments were performed to determine the decrease of serum CK B activity during four months' storage at $-80^{\circ} \mathrm{C}$. Twenty-four sera, analysed within 24 hours, showed serum CK B activities that ranged from 9 to $146 \mathrm{U} / \mathrm{l}$. They were then stored at $-80^{\circ} \mathrm{C}$ for four months, after which serum CK $B$ activities were redetermined. The decrease in serum CK B activity averaged 9 per cent and was at most 18 per cent in a single sample.

Serum CK and LD isoenzymes were qualitatively estimated by agarose gel electrophoresis at or around peak total activities of serum CK and LD, respectively. Serum CK isoenzymes were evaluated by NADPH fluorescence after the agarose slides had been incubated with the SCE CK reaction medium. ${ }^{12}$ The detection limit for the CK MB isoenzyme with this procedure was approximately 20 to $25 \mathrm{U} / \mathrm{l}$, estimated by electrophoresis of dilutions of known activities from a nearly pure CK MB preparation from human heart tissue. Serum LD isoenzymes were estimated by the tetrazolium method. ${ }^{20}$

\section{DISCRIMINATION VALUES AND}

DIAGNOSTIC CRITERIA

The discrimination values and diagnostic criteria, respectively, of the different tests are shown in Table 1. The discrimination value for total serum $\mathrm{CK}$ and the diagnostic criteria for the qualitative,

Table 1 Different tests to be evaluated; discrimination values and diagnostic criteria used for classification of patients into acute and non-acute myocardial infarction groups

\begin{tabular}{|c|c|}
\hline Tests & $\begin{array}{l}\text { Discrimination values and diagnostic } \\
\text { criteria }\end{array}$ \\
\hline $\begin{array}{l}\text { Total serum CK } \\
\text { Serum CK B } \\
\text { Serum CK MB (electro- } \\
\text { phoretic estimation) }\end{array}$ & $\begin{array}{l}\geqslant 350 \mathrm{U} / 1 \\
\geqslant 12 \mathrm{U} / 1 \\
\text { Demonstrable on } \mathrm{CK} \text { electrophoresis }\end{array}$ \\
\hline Serum AST and ALT & $\begin{array}{l}\text { Two AST values }>40 \mathrm{U} / 1 \text { with } \\
\text { maximal activity about } 24 \text { hours after } \\
\text { onset of symptons; AST }>\text { ALT } \\
\text { about } 36 \text { hours after onset of } \\
\text { symptoms }\end{array}$ \\
\hline $\begin{array}{c}\text { Serum LD H4 (electro- } \\
\text { phoretic estimation) }\end{array}$ & Increased on LD electrophoresis \\
\hline Electrocardiogram & "Diagnostic" (see text) \\
\hline
\end{tabular}

electrophoretic estimations of $\mathrm{CK}$ isoenzyme $\mathrm{MB}$ and $\mathrm{LD}$ isoenzyme $\mathrm{H}_{4}$, respectively, were selected on the basis of a previous study. ${ }^{21}$ In order to avoid too many false-positive total serum $\mathrm{CK}$ results, the acute myocardial infarction discrimination limit for this test was set $\mathbf{4 0}$ per cent higher than the upper reference limit in a group of healthy male blood donors.

The diagnostic criterion for the serum AST-ALT relation, hereafter called AST, was that used in the coronary care unit. The acute myocardial infarction discrimination value for serum CK B activity, determined by the present immunoinhibition method, was selected on the basis of data previously published by us. ${ }^{16}$ The standard 12 lead electrocardiogram was considered diagnostic of an acute myocardial infarction if one or more of the following characteristics were present:

(1) Development of a pathological $Q$ wave in two or more leads.

(2) Development, or regression, of a localised ST segment elevation followed by $T$ wave inversion in two or more leads.

(3) Development of a pathological $R$ progression in praecordial leads.

\section{CLASSIFICATION OF PATIENTS}

Independently of the serum CK B results, patients were classified into acute myocardial infarction and non-acute myocardial infarction groups. For this classification the following three systems were used.

(1) Classification based on the following five tests: (a) total serum CK; (b) serum CK MB (electrophoretic estimation); (c) serum LD $\mathrm{H}_{4}$ (electrophoretic estimation); (d) serum AST; and (e) electrocardiogram.

The activities of the quantitative enzyme tests in this system were the maximal values measured in each individual patient. Electrophoretic estimations of serum $\mathrm{CK} M B$ and serum $\mathrm{LD} \mathrm{H}_{4}$ were carried out on samples at or around peak total activities of $C K$ and $L D$, respectively. If any four of the five tests were positive, the patient was classified as a case of acute myocardial infarction. Conversely, if any four were negative, the patient was classified as a case of non-acute myocardial infarction.

(2) Classification according to necropsy findings. Patients were classified as cases of acute myocardial infarction if an infarct of fitting age was found at necropsy.

(3) Classification according to the WHO criteria for definite acute myocardial infarction. ${ }^{22}$ In doubtful cases, however, the results of the electrophoretic determination of the $\mathrm{CK}$ isoenzyme $\mathrm{MB}$ were also taken into account. 
All but 11 patients were classifiable according to (1) or (2). Among these, there were no discrepancies between the classification systems applied. The 11 remaining cases, constituting 5 per cent of the total patients, were classified according to (3).

The independent ability of the serum CK B determination to classify patients into these groups was then investigated and expressed as predictive values of positive and negative test results (see below). For comparison with serum CK B the discrimination abilities of each of the other enzyme tests and of the electrocardiogram were also assessed. When evaluating tests other than serum CK $B$, patients were divided into acute myocardial infarction and non-acute myocardial infarction groups according to the classification systems described above. However, when applying system (1) patients were defined as cases of acute myocardial infarction if, without reference to the particular test being evaluated (total serum $\mathrm{CK}$, serum $\mathrm{CK}$ $\mathrm{MB}$, serum $\mathrm{LD} \mathrm{H}_{4}$, serum AST, and electrocardiogram) at least three of the four remaining tests were positive. Conversely, they were characterised as non-acute case of myocardial infarction if, without reference to the particular test being evaluated, at least three of the four remaining tests were negative. Consequently, serum CK B was never used for classification into acute myocardial infarction and non-acute myocardial infarction groups, as the principal aim of the study was to evaluate this particular test.

PREDICTIVE VALUES OF INDIVIDUAL TESTS The diagnostic ability of the five enzyme determinations (total CK, CK B, AST, CK MB electrophoretically, $\mathrm{LD} \mathrm{H}$, electrophoretically) and of the electrocardiogram was expressed as predictive values of each test, calculated according to the principles of conditional probability (Bayes' theorem). ${ }^{23}$

Predictive value of a positive test result (PV pos) $=$ No. of diseased subjects with positive test result No. of all subjects with positive test result

Predictive value of a negative test result (PV neg) $=$ No. of non-diseased subjects with negative test result

No. of all subjects with negative test result

\section{Results}

TIME COURSE OF ENZYME PATTERNS IN SOME PATIENTS

Enzyme patterns from some patients are graphically shown in Fig. 1 to 4 . Fig. 1 represents a 67-year-old woman who suffered chest pain two to three hours before admission. With the discrimination limits,

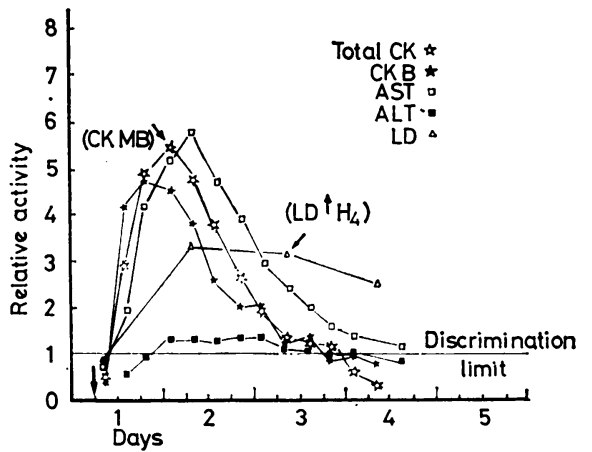

Fig. 1 Enzyme pattern of a 67-year-old woman with acute myocardial infarction. For case history, see text. Relative activities of enzymes (ordinate) are plotted as a function of time after onset of symptoms, marked by the heavy arrow. The horizontal line at 1 on the ordinate represents the acute myocardial infarction discrimination limit for each enzyme. The curves depict the time courses of the activities in serum of the enzymes total $C K, C K B, A S T, A L T$, and $L D$, as designated by the symbols on the graph. Symbols in parentheses (CK $\mathrm{MB})\left(\mathrm{LD} \mathrm{H}_{4}\right.$ ) indicate the point in time at which a qualitative isoenzyme electrophoresis was carried out.

total CK, AST, and LD were increased by factors of up to about 5, 6, and 3, respectively. Serum ALT was only slightly increased. Electrophoretically, CK MB was detectable and $\mathrm{LD} \mathrm{H}_{4}$ was increased. On the basis of these enzyme data this patient was classified as having acute myocardial infarction, even though the electrocardiogram was not conclusive for an acute myocardial infarction. Serum CK B results were in accord with the diagnosis of acute myocardial infarction, being increased to a maximal value of about five times the discrimination limit.

Fig. 2 illustrates the clinical sensitivity of the serum CK B method. A 51-year-old woman, with a previous history of ischaemic heart disease, was

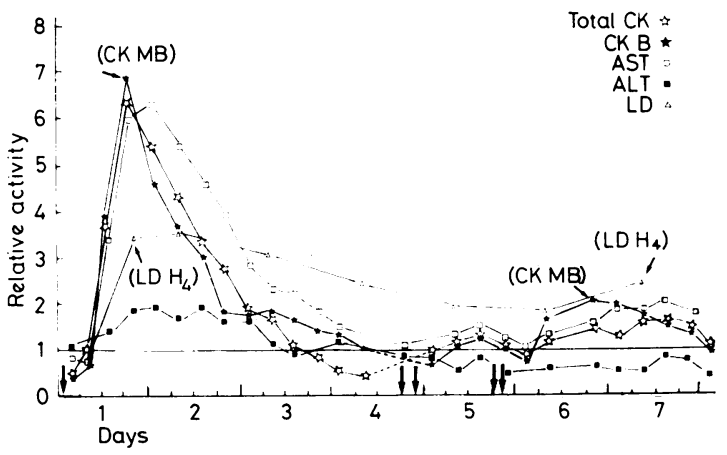

Fig. 2 Enzyme patterns in a 51-year-old woman with acute myocardial infarction. For case history, see text. For description of symbols : see legend to Fig. 1. 
admitted with chest pain starting one hour before admission. Total serum CK and AST activities had increased rapidly to peak values of about six times their respective discrimination limits, by about 18 and 24 hours, respectively, after the onset of pain. Serum ALT activity was constantly lower than that of serum AST. CK MB was electrophoretically demonstrable at peak total serum CK activity, and serum $\mathrm{LD} \mathrm{H}_{4}$ was increased on $\mathrm{LD}$ electrophoresis in accord with the diagnosis of acute myocardial infarction. Electrocardiograms showed unequivocal signs of an inferior wall infarct. Serum CK B was in full agreement with the diagnosis of acute myocardial infarction, being rapidly increased to an initial maximal value about seven times the acute myocardial infarction discrimination limit. On the fourth day after admission the patient again suffered repeated attacks of chest pain (arrows in figure). These attacks were followed by increased activities of serum CK B, total serum CK, and serum AST above their respective discrimination limits. On the fifth day after admission new attacks of chest pain occurred (arrows in figure). This episode of pain was also followed by distinctly increased activities of serum CK B, total CK, and AST.

Consequently, in this case serum CK B, as well as total serum CK and AST, permitted demonstration of three episodes of myocardial enzyme release during seven days.

Fig. 3 illustrates the ability of the serum CK B method to distinguish between enzyme release from myocardial and skeletal muscle tissue. A 63-yearold man was admitted with symptoms suggesting acute myocardial infarction during four hours before arrival. According to the criteria described above he was classified as a case of acute myocardial infarction. Within 24 hours after admission, total

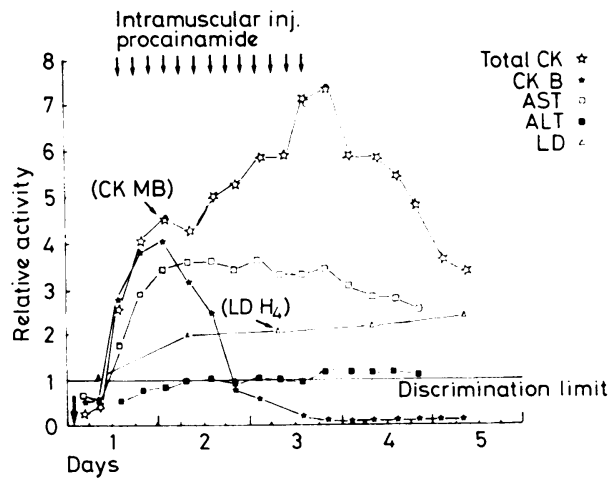

Fig. 3 Enzyme patterns in a 63-year-old man with acute myocardial infarction. For case history, see text. For description of symbols, see legend to Fig. 1.

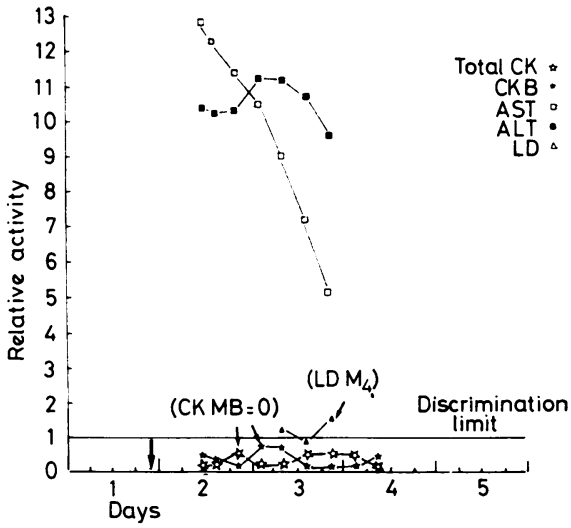

Fig. 4 Enzyme patterns in a 75-year-old man without acute myocardial infarction. For case history, see text. For description of symbols, see legend to Fig. 1.

serum CK, serum CK B, serum AST, and serum LD were increased by factors of about $4,4,3$, and 2 , relative to their respective discrimination limits. Serum ALT constantly remained around the discrimination limit. Shortly after admission, the patient developed ventricular arrhythmias which were treated with procainamide administered intramuscularly at four-hour intervals (arrows in Fig. 3). As long as these repeated intramuscular injections were given, total serum CK activity remained high. After the injections were discontinued, total serum $\mathrm{CK}$ activity rapidly decreased. Conversely, serum CK B activity was not influenced by the injections, but showed a rapidly decreasing activity after the initial peak.

\section{Comment}

The serum CK B curve indicated that enzyme release from injured myocardial tissue ceased early in the course of the disease. Conversely, the prolonged increase of the total serum CK activity probably reflected enzyme release from skeletal muscle after the intramuscular injections.

Fig. 4 demonstrates the clinical specificity of serum CK B. A 75-year-old man was admitted to the coronary care unit with chest pain which had lasted 12 hours. Total serum CK was not increased above the acute myocardial infarction discrimination limit and CK MB was not electrophoretically demonstrable. Serum AST and ALT were already high at admission, but declined during the observation period. The AST/ALT relation changed early, serum ALT exceeding AST about 24 hours after onset of symptoms. This was not characteristic of an acute myocardial infarction but rather indicated the liver as the source of enzyme release. This was further supported by an increased LD $\mathbf{M}_{\mathbf{4}}$ 
isoenzyme fraction and a normal $\mathrm{LD} \mathrm{H}_{4}$ fraction on LD electrophoresis about 48 hours after the onset of symptoms. On the basis of these enzyme data, the patient was classified as having no acute myocardial infarction. This was supported by the electrocardiographic findings which showed no signs of myocardial injury. Serum CK B, by remaining well below the discrimination limit throughout the observation period, also lent support to this diagnosis. Among other laboratory data, there was a very high S-bilirubin and a biliary tract occlusion was later demonstrated.

\section{CLASSIFICATION OF PATIENTS}

According to the criteria for acute myocardial infarction and non-acute myocardial infarction, mentioned above, the total 238 cases were classifiable into 113 with acute myocardial infarction and 125 with non-acute infarction. The prevalence of acute myocardial infarction was $\mathbf{0 . 4 7}$.

\section{PREDICTIVE VALUES OF DIFFERENT TESTS}

Predictive values of the different tests are shown in Table 2. All tests, except the electrocardiogram, showed relatively high predictive values for a negative test. The electrocardiogram had the poor predictive value for a negative test result of 0.74 , because of a high proportion of false negative electrocardiograms. The predictive value for a negative test of serum CK B was 0.99, corresponding to 1 per cent false negatives. The predictive values for positive tests of serum AST and of total serum CK were relatively poor as a consequence of a fairly high proportion of false positive serum AST and total serum CK results.

Table 2 Predictive values of each test

\begin{tabular}{|c|c|c|c|c|c|c|c|}
\hline & Neg & Pos & & & $\mathrm{Neg}$ & Pos & \\
\hline $\begin{array}{l}\text { AMI } \\
\text { Non-AMI } \\
\text { Total }\end{array}$ & $\begin{array}{r}1 \\
121 \\
122\end{array}$ & $\begin{array}{r}112 \\
4 \\
116\end{array}$ & $\begin{array}{l}113 \\
125 \\
238\end{array}$ & $\begin{array}{l}\text { AMI } \\
\text { Non-AMI } \\
\text { Total }\end{array}$ & $\begin{array}{r}3 \\
125 \\
128\end{array}$ & $\begin{array}{r}110 \\
0 \\
110\end{array}$ & $\begin{array}{r}113 \\
-125 \\
238\end{array}$ \\
\hline \multicolumn{4}{|c|}{$\begin{aligned} \text { S-CK B } & \text { PV pos } 0.97 \\
& \text { PV neg } 0.99\end{aligned}$} & \multicolumn{4}{|c|}{$\begin{aligned} \text { CK MB PV pos } 1.0 \\
\text { PV neg } 0.98\end{aligned}$} \\
\hline $\begin{array}{l}\text { AMI } \\
\text { Non-AMI } \\
\text { Total }\end{array}$ & $\begin{array}{r}5 \\
106 \\
111\end{array}$ & $\begin{array}{r}108 \\
19 \\
127\end{array}$ & $\begin{array}{l}113 \\
125 \\
238\end{array}$ & $\begin{array}{l}\text { AMI } \\
\text { Non-AMI } \\
\text { Total }\end{array}$ & $\begin{array}{r}1 \\
110 \\
111\end{array}$ & $\begin{array}{r}112 \\
15 \\
127\end{array}$ & $\begin{array}{l}113 \\
125 \\
238\end{array}$ \\
\hline $\begin{array}{l}\text { Total } \\
\text { S-CK }\end{array}$ & \multicolumn{3}{|c|}{$\begin{array}{l}\text { PV pos } 0.85 \\
\text { PV neg } 0.95\end{array}$} & $\begin{array}{ll}\mathbf{S}-\mathbf{A S T} & \mathbf{P} \\
\mathbf{P}\end{array}$ & \multicolumn{3}{|c|}{$\begin{array}{l}\text { PV pos } 0.88 \\
\text { PV neg } 0.99\end{array}$} \\
\hline $\begin{array}{l}\text { AMI } \\
\text { Non-AMI } \\
\text { Total }\end{array}$ & $\begin{array}{r}7 \\
123 \\
130\end{array}$ & $\begin{array}{r}106 \\
2 \\
108\end{array}$ & $\begin{array}{l}113 \\
125 \\
238\end{array}$ & $\begin{array}{l}\text { AMI } \\
\text { Non-AMI } \\
\text { Total }\end{array}$ & $\begin{array}{r}43 \\
125 \\
168\end{array}$ & $\begin{array}{r}70 \\
0 \\
70\end{array}$ & $\begin{array}{l}113 \\
125 \\
238\end{array}$ \\
\hline LD H & \multicolumn{3}{|c|}{$\begin{array}{l}\text { PV pos } 0.98 \\
\text { PV neg } 0.95\end{array}$} & ECG & \multicolumn{3}{|c|}{$\begin{array}{l}\text { PV pos } 1.0 \\
\text { PV neg } 0.74\end{array}$} \\
\hline
\end{tabular}

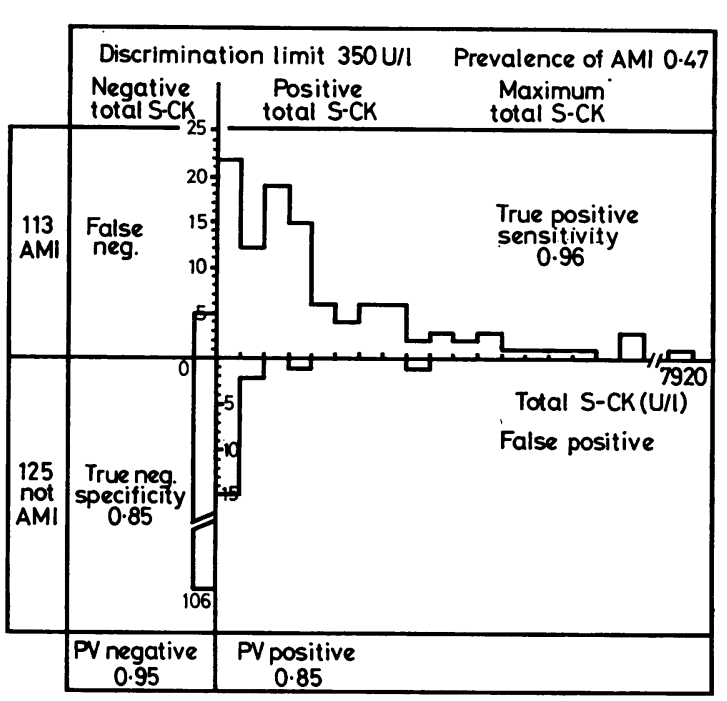

Fig. 5 Frequency histogram of maximal total serum $C K$ activities in each of 113 cases with acute myocardial infarction and 125 cases with non-acute myocardial infarction.

Abscissa: Total serum $C K$ activities in steps of $350 \mathrm{U} / \mathrm{l}$. The discrimination limit of $350 \mathrm{U} / \mathrm{l}$ is at the intersection with the ordinate. "Negative" total serum CK activities to the left of the ordinate, "positive" total serum CK activities to the right.

Ordinate: Number of patients within each total serum $C K$ interval can be read from height of each column.

Classification: Acute myocardial infarction cases upper panel. Non-acute myocardial infarction cases, lower panel. Correlation: False-negative and true-positive total serum $C K$ values in left and right upper quadrants, respectively. True-negative and false-positive total serum $C K$ values in left and right lower quadrants, respectively.

The predictive values for other positive tests were relatively high: that for serum CK $B$ was 0.97. False positive serum CK B results were obtained in four cases which will be discussed separately below.

\section{Comment}

The predictive values for the electrophoretic estimations of serum $\mathrm{CK} \mathrm{MB}$ and $\mathrm{LD} \mathrm{H}_{4}$ were unexpectedly high, probably because the electrophoreses were consistently carried out on one or more samples at or around peak total activities of serum $C K$ and $L D$, respectively.

\section{DISTRIBUTION OF TOTAL SERUM CK AND} SERUM CK B ACTIVITIES

Fig. 5 shows the distribution of the maximal total serum CK value from each of the 238 patient cases. Fig. 6 shows the corresponding data for the serum CK $B$ values. The two histograms permit identi- 
fication of the number of false and correct results obtained by the two enzyme tests.

ENZYME ACTIVITIES IN RELATION TO TIME AFTER ONSET OF ACUTE SYMPTOMS

In 55 patients with acute myocardial infarction with increased activities of serum CK B, total CK, and AST above their respective discrimination limits, we were able to define distinctly the time when the acute symptoms began. The enzyme data of these patients were used to illustrate the probabilities of serum CK B, total CK, and AST being increased above their respective discrimination limits at a certain time after the onset of acute symptoms. Fig. 7 shows the patients with acute myocardial infarction who had CK $B$ activities above the discrimination limit of $12 \mathrm{U} / 1$, as a function of time after the onset of symptoms. Fig. 8 and 9 show the corresponding data for total serum CK and AST, respectively. Serum activities of CK B and total CK of all patients exceeded the discrimination limits within 12 hours after the onset of symptoms. The corresponding time for serum AST was 16 hours. On the other hand, serum activities of CK $B$ and total CK returned to below the respective discrimination limits earlier than

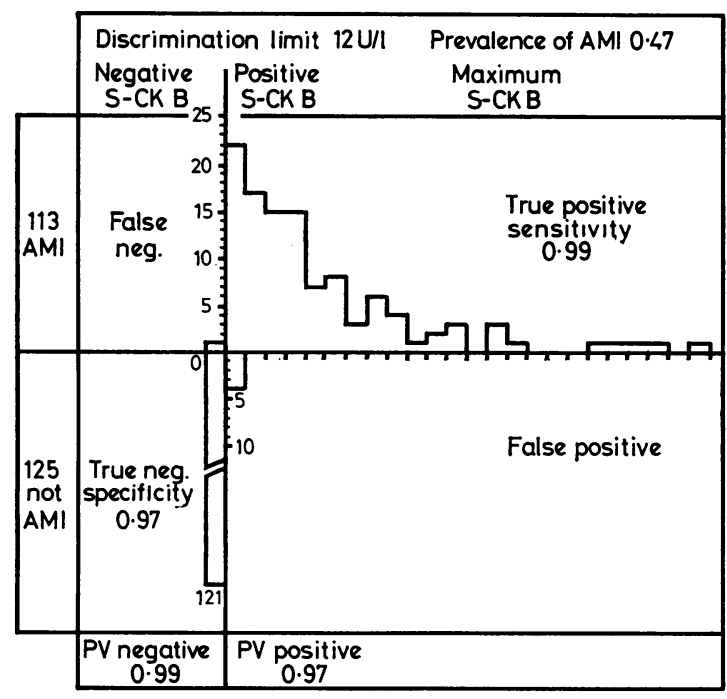

Fig. 6 Frequency histogram of maximal serum $C K B$ values in each of 113 cases with acute myocardial infarction and 125 cases with non-acute myocardial infarction.

Abscissa: Serum CK B activities in steps of $12 \mathrm{U} / \mathrm{l}$. The discrimination limit of $12 \mathrm{U} / \mathrm{l}$ is at the intersection with the ordinate. "Negative" serum CK B activities to the left of the ordinate, "positive" serum CK $B$ activities to the right.

Ordinate, classification, correlation: See legend to Fig. 5 those of AST. This is illustrated in Fig. 7 and 8 by the decreasing number of patients with serum CK $B$ and total serum CK activities above their respective discrimination limits at 22 and 16 hours after the onset of symptoms. For comparison, all patients still had increased serum AST values 36 hours after onset of symptoms (Fig. 9).

\section{Discussion}

As long-term frozen sera were used for determination of serum CK B activities in 113 of the 238 cases, we studied the decrease in serum CK B activity during storage for four months at $-80^{\circ} \mathrm{C}$ (see above). Data from these control experiments, together with the serum CK B results obtained in long-term frozen sera, indicated that storage under the described conditions did not change the CK B activities sufficiently to influence the predictive values obtained for this test. Consequently, we were able to use samples from all the patients when evaluating serum $C K B$.

Use of serum CK B activity, as an indicator of acute myocardial infarction, presupposes that all CK B subunit dependent activity in serum derives from myocardial $\mathrm{CK}$ isoenzyme $\mathrm{MB}$. The possible occurrence of $\mathrm{CK}$ isoenzyme $\mathrm{BB}$ in human serum therefore implies a potential risk of a CK BB induced rise in serum CK $B$ activity being mistaken for a manifestation of acute myocardial infarction. Consequently, in order to optimise the diagnostic power of the serum CK B determination, it is important to be aware of some clinical conditions in which CK BB may be present in serum. Detectable serum CK BB activity is reported in a variety of conditions, even if opinions concerning the occurrence of this isoenzyme in many of these instances are contradictory.

Conditions recurringly reported as possible causes of serum CK BB activity are cerebral diseases and injuries, ${ }^{24-26}$ some malignant diseases, ${ }^{27-29}$ chronic uraemia, ${ }^{30-32}$ some nervous system disorders, such as "floppy infant syndrome", and Werdnig-Hoffman's disease. ${ }^{33}$ Most of these conditions, however, do not present any differential diagnostic problems in relation to acute myocardial infarction. Another cause of detectable serum CK BB activity is anoxic brain injury after cardiac arrest. ${ }^{24} 25$ In this situation, an increased serum CK B value may be difficult to assess, as it can derive from $\mathrm{CK} M B, C K \mathrm{BB}$, or both. The problem is illustrated in two of our patients with false-positive serum CK B results. In both cases increased serum CK B activities occurred as a consequence of the transient presence of $\mathrm{CK} \mathrm{BB}$ in the serum. 


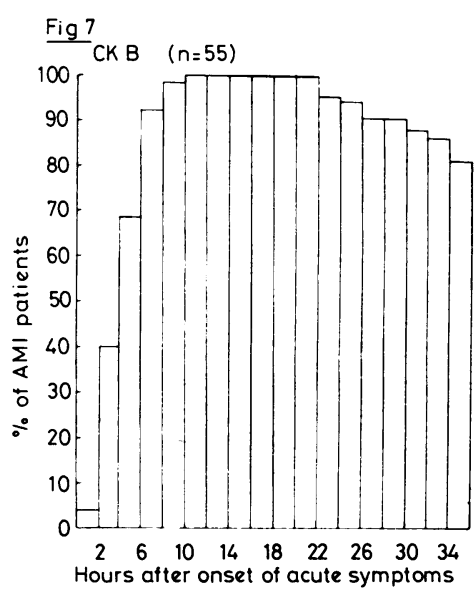

Fig. 7 Proportion of 55 patients with acute myocardial infarction showing positive serum $C K B$ activities as a function of time after onset of acute symptoms.

Ordinate: Percentage of 55 patients with acute myocardial infarction.

Abscissa: Time interval (hours)

after onset of acute symptoms.

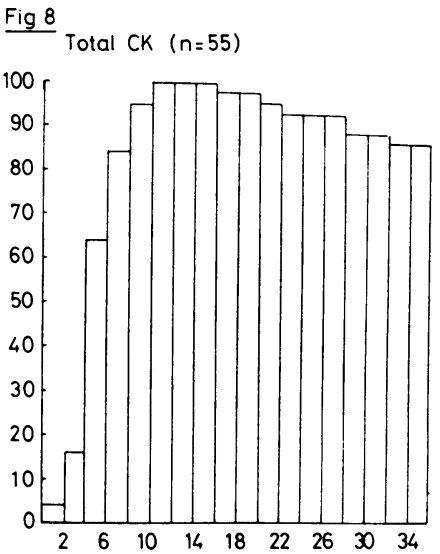

Fig. 8 Proportion of 55 patients with acute myocardial infarction showing positive total serum $C K$ activities as a function of time after onset of acute symptoms. See also legend to Fig. 7.

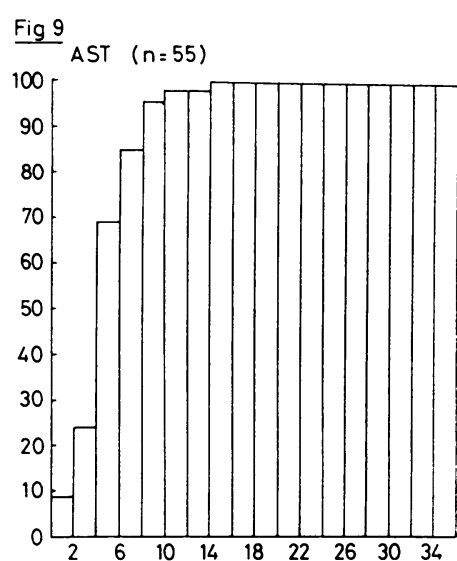

Fig. 9 Proportion of 55 patients with acute myocardial infarction with positive serum $A S T$ activities as a function of time after onset of acute symptoms. See also legend to Fig. 7.
One of the patients was a 58-year-old man with cardiac arrest (Fig. 10). The electrocardiogram on arrival showed ventricular fibrillation. Normal heart action was immediately restored by defibrillation. The patient survived, but remained unconscious for about 20 hours after resuscitation; continuous electrocardiographic monitoring disclosed frequent ventricular arrhythmias. The enzyme data, as shown in Fig. 10, with serum ALT activity exceeding that of AST activity, total serum CK activity below the acute myocardial infarction discrimination limit, absence of $\mathrm{CK} M B$ on $\mathrm{CK}$ electrophoresis, and an increased LD $\mathrm{M}_{4}$ fraction together with a normal LD $\mathrm{H}_{4}$ fraction on $\mathrm{LD}$ electrophoresis made this patient classifiable as a non-infarction case. This diagnosis was further supported by the electrocardiogram which showed no signs of myocardial damage. The transient serum CK B elevation in the admission sample was a result of the serum CK BB activity, as shown on CK electrophoresis.

We previously described an additional group of patients with CK BB in the serum and consequently increased serum CK $B$ activity. ${ }^{19}$ In these patients, the BB isoenzyme had an abnormal electrophoretic mobility and was not associated with any known disease. Such patients are recognised by the combination with increased serum $C K$ B activity despite normal, or close to normal, total serum CK activity. In the present patient series, one patient with non-acute myocardial infarction with falsepositive serum CK B result might represent this group. The patient was a 76-year-old woman with a constant slightly increased serum CK B activity of about 12 to $14 \mathrm{U} / 1$ in spite of normal total serum $\mathrm{CK}$ and other enzyme activities. On serum CK electrophoresis only regularly migrating isoenzyme $M M$ was visible while no isoenzyme band corresponding to the increased serum CK $B$ activity was shown. This, however, might be a consequence of the relatively low serum CK B activity which corresponds to $\mathrm{BB}$ isoenzyme

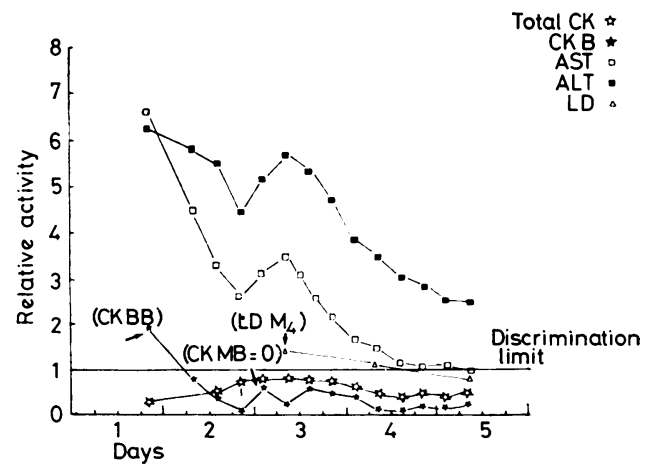

Fig. 10 Enzyme patterns in a 58-year-old man with cardiac arrest but no acute myocardial infarction. For case history, see text. For description of symbols, see legend to Fig. 1. 
activity which may fail to reach the detection limit of the electrophoretic procedure.

The remaining false-positive serum CK B result appeared in a patient suffering from repeated attacks of chest pain with concomitant electrocardiographic abnormalities of the Prinzmetal variant angina type. According to the applied classification systems he was classified as a case of non-acute myocardial infarction. However, it is possible that the transient and slight increase in serum CK B activity corresponded to a true but very small myocardial infarction.

The main advantage of the serum CK B analysis, as compared with total serum CK and serum AST determinations, is the increase of the predictive value of a positive test result because of the lower proportion of false-positive results. The relatively poor predictive values of a positive test result of total serum CK and AST mainly reflect the fact that these serum enzyme activities are influenced by many non-cardiac conditions. Thus, total serum CK is often raised after various therapeutic and diagnostic interventions, such as intramuscular injections, ${ }^{34}$ and cardioversion. ${ }^{35}$ On the other hand, the predictive values of a negative test result of total CK and AST are similar to that of CK B, indicating the same low proportion of false negative results.

The electrophoretic, qualitative estimations of $C K$ and $L D$ isoenzymes gave about the same predictive values as did serum CK B. The electrophoreses were always performed on one or more samples at or around the peak total activities of the respective enzymes, thus giving optimal test conditions. However, electrophoretic estimation of LD isoenzymes may be particularly useful in patients with delayed admission after the onset of symptoms indicating an acute myocardial infarction. In such cases, the determinations of total serum CK and serum CK $B$ are less suited for the diagnosis of acute myocardial infarction, caused by the transient nature of their serum activity increases after an acute myocardial infarction. ${ }^{36}$

In conclusion, the serum CK B determination is a test of high clinical specificity and sensitivity in the early diagnosis of acute myocardial infarction. The method is relatively simple and rapid, and is well suited for the routine clinical laboratory.

\section{Note added in proof}

A complete description of the updated method for serum CK $B$ determination using an improved CK $M$ subunit antibody has recently been published. ${ }^{37}$
This investigation was supported by grants from the Thorsten and Elsa Segerfalk's Foundation, Helsingborg, from the Malmöhus läns Allmzänna försäkringskassa, and from Mrs Maria Embring, Helsingborg.

\section{References}

${ }^{1}$ Konttinen A, Somer H. Determination of serum creatine kinase isoenzymes in myocardial infarction. Am 7 Cardiol 1972; 29: 817-20.

${ }^{2}$ Klein MS, Shell WE, Sobel BE. Serum creatine phosphokinase (CPK) isoenzymes following intramuscular injections, surgery and myocardial infarction. Experimental and clinical studies. Cardiovasc Res 1973; 7: 412-8.

${ }^{3}$ Roberts R, Sobel BE. Isoenzymes of creatine phosphokinase and diagnosis of myocardial infarction. Ann Intern Med 1973; 79: 741-3.

"Wagner GS, Roe CR, Limbird LE. The importance of identification of the myocardial-specific isoenzyme of creatine phosphokinase (MB form) in the diagnosis of acute myocardial infarction. Circulation 1973; 47: 263-9.

${ }^{5}$ Blomberg DJ, Kimber WD, Burke MD. Creatine kinase isoenzymes; predictive value in the early diagnosis of acute myocardial infarction. $\mathrm{Am} \mathrm{f}$ Med 1975; 59: 464-9.

${ }^{6}$ Smith AF, Radford D, Wong CP, Oliver MF. Creatine kinase $M B$ isoenzyme studies in diagnosis of myocardial infarction. Br Heart $\mathcal{F}$ 1976; 38: 225-32.

'Somer H, Konttinen A. Demonstration of serum creatine kinase isoenzymes by fluorescence technique. Clin Chim Acta 1972; 40: 133-7.

${ }^{8}$ Mercer DW. Separation of tissue and serum creatine kinase isoenzymes by ion-exchange column chromatography. Clin Chem 1974; 20: 36-40.

'Henry PD, Roberts R, Sobel BE. Rapid separation of plasma creatine kinase isoenzymes by batch adsorption on glass beads. Clin Chem 1975; 21 : 844-9.

${ }^{10}$ Nealon DA, Henderson AR. Separation of creatine kinase isoenzymes in serum by ion-exchange column chromatography (Mercer's method, modified to increase sensitivity). Clin Chem 1975; 21: 392-7.

${ }^{11}$ Morin LG. Improved separation of creatine kinase cardiac isoenzyme in serum by batch fractionation. Clin Chem 1976; 22: 92-7.

${ }^{12}$ Neumeier D, Hofstetter R. Radioimmunoassay for subunit $B$ in isoenzymes $C K M B$ and $C K$ BB of creatine phosphokinase. Clin Chim Acta 1977; 79: 107-13.

${ }^{13}$ Roberts R, Parker CW, Sobel BE. Detection of acute myocardial infarction by radioimmunoassay for creatine kinase MB. Lancet 1977; 2: 319-22.

${ }^{14}$ Neumeier D, Prellwitz W, Würzburg U, et al. Determination of creatine kinase isoenzyme MB activity in serum using immunological inhibition of creatine kinase M subunit activity. Clin Chim Acta 1976; 73: 445-51.

${ }^{15}$ Gerhardt $W$, Ljungdahl L, Borjesson J, et al. Creatine kinase B-subunit activity in serum I. Development of an immunoinhibition method for routine determination 
of S-creatine kinase B-subunit activity. Clin Chim Acta 1977; 78: 29-41.

${ }^{16}$ Ljungdahl L, Hofvendahl S, Gerhardt W, Börjesson J. Creatine kinase B-subunit activity in human serum. II. Evaluation of S-CK B-subunit activity in the diagnosis of acute myocardial infarction. Clin Chim Acta 1977; 78: 43-53.

${ }^{17}$ Scandinavian Society for Clinical Chemistry and Clinical Physiology, Committee on Enzymes. Recommended methods for determination of four enzymes in blood. Scand f Clin Lab Invest 1974; 33: 291-306.

${ }^{18}$ Scandinavian Society for Clinical Chemistry and Clinical Physiology, Committee on Enzymes. Recommended method for determination of creatine kinase in blood. Scand f Clin Lab Invest 1976; 36: 711-23.

${ }^{19}$ Ljungdahl L, Gerhardt W. Creatine kinase isoenzyme variants in human serum. Clin Chem 1978; 24: 832-4.

${ }^{20}$ Rosalki SB. Standardisation of isoenzyme assays with special reference to lactate dehydrogenase isoenzyme electrophoresis. Clin Biochem 1974; 7: 29-40.

${ }^{21}$ Gerhardt W, Hofvendahl S. Evaluation of enzyme determinations in myocardial infarction. In: Burlina A, Galzigna L, eds. 7th international symposium on clinical enzymology, Venezia 1976. Clinical enzymology symposium 1. Padua: Piccin Medical Books, 1977: 223-37. ${ }^{22}$ World Health Organization. Regional office for Europe. Evaluation of comprehensive rehabilitative and preventive programmes for patients after acute myocardial infarction. Copenhagen: WHO, 1971-1972.

${ }^{23}$ Sunderman FW Jr. Current concepts of "normal values", "reference values", and "discrimination values" in clinical chemistry. Clin Chem 1975; 21: 1873-7.

${ }^{24}$ Itano $\mathrm{M}$. The detection of $\mathrm{CPK}_{1}(\mathrm{BB})$ in serum. Am $\mathcal{F}$ Clin Pathol 1976; 65: 351-5.

${ }^{25}$ Kaste M, Somer H, Konttinen A. Brain-type creatine kinase isoenzyme. Occurrence in serum in acute cerebral disorders. Arch Neurol 1977; 34: 142-4.

${ }^{26}$ Somer $H$, Kaste $M$, Konttinen A. Creatine kinase isoenzymes in the serum in acute cerebral damage (abstract). Clin Chem 1977; 23: 1142.

${ }^{27}$ Coolen RB, Pragay D. The production of brain type creatine kinase in the serum of patients with oat-cell carcinoma (abstract). Clin Chem 1976; 22: 1174-5.

${ }^{28}$ Lederer $W H$, Gerstbrein HL. Creatine kinase isoenzyme BB activity in serum of a patient with gastric cancer. Clin Chem 1976; 22: 1748-9.

${ }^{29}$ Feld RD, Witte DL. Presence of creatine kinase BB isoenzyme in some patients with prostatic carcinoma. Clin Chem 1977; 23: 1930-2.

${ }^{30}$ Byrnes AC, Alter S. Important to separate creatine kinase isoenzyme BB? Clin Chem 1975; 21 : 1845.

${ }^{31}$ Marmor A, Grenadier E, Palant A. Assay of creatine kinase isoenzymes in heart disease. Lancet 1977; 2: 1087-8.

${ }^{32}$ Weseley SA, Byrnes A, Alter S, Solangi KB, Goodman AJ. Presence of creatine phosphokinase brain band in the serum of chronic renal disease patients. Clin Nephrol 1977; 8: 345-8.

${ }^{33}$ Jockers-Wretou E, Grabert K, Müller E, Pfleiderer G. Serum creatine kinase isoenzyme pattern in nervous system atrophies and neuromuscular disorders. Clin Chim Acta 1976; 73: 183-6.

${ }^{34}$ Meltzer HY, Mrozak S, Boyer M. Effect of intramuscular injections on serum creatine phosphokinase activity. Am $\mathcal{F}$ Med Sci 1970; 259: 42-8.

${ }^{35}$ Ehsani A, Ewy CA, Sobel BE. Effects of electrical countershock on serum creatine phosphokinase (CPK) isoenzyme activity. Am $\mathcal{F}$ Cardiol 1976; 37: 12-8.

${ }^{36}$ Nordlander $R$. Enzymes in the diagnosis of acute myocardial infarction with special reference to creatine kinase MB isoenzyme. Acta Med Scand suppl: 1978; 623: $18-26$.

${ }^{37}$ Gerhardt W, Waldenström J. Creatine kinase Bsubunit activity in serum after immunoinhibition of M-subunit activity. Clin Chem 1979; 25: 1274-80.

Requests for reprints to Dr Lars Ljungdahl, Department of Medicine, Lasarettet, S-251 87, Helsingborg, Sweden. 